\title{
Malnutrisi Rumah Sakit Pada Bangsal Anak Rumah Sakit Dr. Wahidin Sudirohusodo Makassar
}

\author{
Aidah Juliaty \\ Bagian Ilmu Kesehatan Anak FK Universitas Hasanuddin/RSU Wahidin Sudirohusodo, Makassar
}

\begin{abstract}
Latar belakang. Malnutrisi rumah sakit (MRS) ditandai dengan penurunan berat badan saat dirawat di rumah sakit. Kejadian MRS erat kaitannnya dengan dukungan nutrisi selama perawatan.

Tujuan. Menentukan prevalensi MRS pada pasien yang dirawat di bangsal anak Rumah Sakit Dr. Wahidin Sudirohusodo, Makassar.

Metode. Penelitian observasional kohort retrospektif yang berlangsung dari Januari sampai Desember 2011 di Rumah Sakit Dr Wahidin Sudirohusodo, Makassar. Jumlah sampel 1268 menggunakan indikator berat badan menurut tinggi badan (BB/TB) menurut CDC 2000.

Hasil. Prevalensi MRS perempuan 0,12\%, dan laki-laki 0,11\%. Tertinggi 0,16\% pada kelompok umur 2536 bulan, dan terendah 0,03\% pada kelompok umur 49-60 bulan. Pada kelompok subyek tersebut, 0,15\% dengan diagnosis multipel, $0,05 \%$ dengan diagnosis tunggal, $0,27 \%$ status gizi buruk, $0,12 \%$ gizi kurang, dan 0,8\% gizi baik. Dari subdivisi infeksi diperoleh kejadian MRS 0,17\%, dan non infeksi 0,07\%(OR 1,1), serta lama rawat $>7$ hari $0,25 \%$, dan $2-7$ hari $0,07 \%$.

Kesimpulan. Anak yang dirawat lebih dari satu minggu dengan penyakit kronis dan diagnosis multipel mempunyai risiko MRS lebih besar dibandingkan anak yang dirawat kurang dari seminggu. Penyakit infeksi mempunyai faktor risiko lebih besar mengalami MRS daripada penyakit non infeksi.
\end{abstract}

Sari Pediatri 2013;15(2):65-8.

Kata kunci: malnutrisi rumah sakit, bangsal anak.

$\mathrm{M}$ alnutrisi rumah sakit merupakan suatu keadaan akibat dari perhatian yang tidak optimal terhadap status nutrisi anak. Malnutrisi rumah sakit ditandai

\section{Alamat korespondensi:}

Dr. Aidah Juliaty, Sp.A,.Bagian Ilmu Kesehatan Anak Fakultas Kedokteran Universitas Hasanuddin, Jln Perintis Kemerdekaan KM11, Makassar 90245. Telp. (0411) 584461.E-mail:aidah_juliaty@yahoo.com dengan penurunan berat badan saat dirawat di rumah sakit. Kejadian MRS erat kaitannya dengan dukungan nutrisi selama perawatan. ${ }^{1}$ Insiden terjadinya MRS cukup tinggi, Koen $\mathrm{dkk}^{2}$ melaporkan 6,1\%-40,9\%, Marino $\mathrm{dkk}^{5}$ melaporkan 34\%. Dikatakan pula insiden malnutrisi di negara maju berkisar $6,1 \%$ $11 \%$, sedangkan di negara berkembang 6,9\%-53\%. Penelitian di RSCM didapatkan hasil bahwa jumlah anak yang mengalami malnutrisi, setelah perawatan 
14 hari. Rocha $\mathrm{dkk}^{6}$ melaporkan terdapat penurunan berat badan pada $9,17 \%$ pasien dengan status nutrisi normal saat keluar dari rumah sakit.

Malnutrisi rumah sakit akan memengaruhi banyak hal, yaitu lama perawatan yang bertambah, peningkatan mortalitas, penyembuhan yang terlambat, dan peningkatan biaya perawatan. ${ }^{4}$ Kematian oleh malnutrisi erat kaitannya dengan infeksi sehingga mencegah terjadinya MRS atau mendeteksi adanya MRS secara dini dan segera mengatasinya, merupakan tindakan yang bermanfaat baik bagi pasien maupun pengelola rumah sakit.

Pasien mengalami MRS menurut Walker ${ }^{7}$ dan Hendricks, ${ }^{8}$ jika terjadi penurunan berat badan lebih dari 2 persen dalam seminggu atau lebih dari 5 persen dalam sebulan atau lebih dari 7,5 persen dalam 3 bulan atau lebih dari 10 persen dalam 6 bulan. Tujuan dari penelitian ini adalah menentukan prevalensi MRS pada pasien yang dirawat di bangsal anak Rumah Sakit Dr Wahidin Sudirohusodo Makassar.

\section{Metode}

Penelitian observasional kohort retrospektif yang berlangsung dari Januari sampai Desember 2011 di Ruang Perawatan Anak kelas II dan III Rumah Sakit Umum Dr. Wahidin Sudirohusodo. Kriteria inklusi adalah anak usia 0 bulan sampai 18 tahun. Kriteria eksklusi adalah anak yang mengalami retensi cairan, terdapat organomegali, mempunyai massa tumor, dan overweight atau obesitas. Pengukuran berat badan dengan menggunakan seca baby scale dan seca mechanical scale. Sedangkan pengukuran tinggi badan atau panjang badan dengan menggunakan seca infantometer dan seca microtois. Penurunan berat badan yang signifikan, yaitu pada anak yang mengalami penurunan berat lebih dari $2 \%$ selama kurang dari 7 hari perawatan, lebih dari 5\% untuk 7 sampai 30 hari, dan lebih dari $10 \%$ untuk 1 sampai 6 bulan.

Sampel diambil secara consecutive sampling dengan jumlah sampel sebesar 1268. Malnutrisi pada saat masuk rumah sakit ditentukan dengan indikator berat badan menurut tinggi badan (BB/TB) menurut CDC 2000.

\section{Hasil}

Selama periode penelitian tercatat 1286 anak pada rekam medis divisi nutrisi dan penyakit metabolik, terdiri dari 720 (56,0\%) laki-laki, dan 566 (44,0\%) perempuan. Usia terbanyak >60 bulan $513(39,9 \%)$ dan yang paling sedikit adalah 49-60 bulan (4,3\%). Subyek penelitian terbanyak masuk rumah sakit dengan diagnosis multiple, yaitu 765 (59,5\%), dan yang paling sedikit dengan diagnosis tunggal, yaitu 521 (40,5\%). Tergolong gizi baik $606(47,1 \%)$, gizi kurang 566 (44,0\%), dan gizi buruk 114 (8,9\%). Adapun jumlah terbanyak dari subyek penelitian

Tabel 1. Karakteristik dasar pasien

\begin{tabular}{|c|c|c|}
\hline Variabel & $\mathrm{n}$ & $\%$ \\
\hline \multicolumn{3}{|l|}{ Jenis kelamin } \\
\hline Laki laki & 720 & 56,0 \\
\hline Perempuan & 566 & 44,0 \\
\hline \multicolumn{3}{|l|}{ Umur (bulan) } \\
\hline $0-12$ & 343 & 26,7 \\
\hline $13-24$ & 184 & 14,3 \\
\hline $25-60$ & 98 & 7,6 \\
\hline$>60$ & 513 & 39,9 \\
\hline \multicolumn{3}{|c|}{ Status gizi (saat MRS) } \\
\hline Baik & 606 & 47,1 \\
\hline Kurang & 566 & 44,0 \\
\hline Buruk & 114 & 8,9 \\
\hline \multicolumn{3}{|l|}{ Diagnosis } \\
\hline Tunggal & 521 & 40,5 \\
\hline Multipel & 765 & 59,5 \\
\hline \multicolumn{3}{|l|}{ Lama rawat (hari) } \\
\hline $2-7$ & 967 & 75,2 \\
\hline$>7$ & 319 & 24,8 \\
\hline \multicolumn{3}{|c|}{ Kehilangan berat badan (\%) } \\
\hline \multicolumn{3}{|c|}{$<2$} \\
\hline $2-5$ & 1048 & 81,5 \\
\hline$>5-10$ & 122 & 9,5 \\
\hline$>10$ & 85 & 6,6 \\
\hline Jenis penyakit & 31 & 2,4 \\
\hline \multicolumn{3}{|l|}{ Pneumonia } \\
\hline Diare & 123 & 9,6 \\
\hline Tonsilofaringitis & 281 & 21,9 \\
\hline Kejang demam & 124 & 9,6 \\
\hline DBD & 31 & 2,4 \\
\hline Ensefalopati & 28 & 2,2 \\
\hline Leukemia & 54 & 4,2 \\
\hline Anemia & 209 & 16,3 \\
\hline Epilepsi & 36 & 2,8 \\
\hline PJB & 28 & 2,2 \\
\hline Meningitis & 16 & 1,2 \\
\hline Marasmik & 13 & 1,0 \\
\hline \multirow[t]{2}{*}{ Lain-lain } & 7 & 0,5 \\
\hline & 336 & 26,1 \\
\hline
\end{tabular}


adalah dari subdivisi non infeksi, yaitu 775 (60,3\%) dan paling sedikit adalah dari subdivisi infeksi 511 $(39,7 \%)$ dengan lama rawat terbanyak adalah 2-7 hari 967 (75,2\%), dan lebih dari 7 hari 319 (24,8\%). Jenis penyakit terbanyak kedua adalah diare $281(21,9 \%)$, terbanyak ketiga leukemia 209 (16,3\%), dan urutan teratas adalah penyakit lain $336(26,1 \%)$.

Prevalensi MRS pada anak perempuan lebih tinggi dibandingkan anak laki-laki, yaitu $0,12 \%$ berbanding 0,11\% (OR 0,91;CI95\%:0,649-1,285), terbanyak 0,16\% pada kelompok umur 25-36 bulan dan paling sedikit 0,03\% pada kelompok umur 49-60 bulan. Diagnosis tunggal 0,05\% dibandingkan dengan diagnosis multiple 0,15\% (OR 0,314;CI95\%:0,206$0,478)$, status gizi buruk terbanyak $0,27 \%$ dibandingkan gizi kurang $0,12 \%$, dan gizi baik $0,8 \%$. Penyakit non infeksi 0,07\% dibandingkan infeksi 0,17\% (OR 0,405;CI95\%: 0,286-0,573), serta lama rawat 2-7 hari $0,07 \%$ dibandingkan lebih dari 7 hari $0,25 \%$ (OR 0,233; CI95\%:0,164-0,331).

Semua variabel diuji secara statistik dengan uji bivariate. Hasil masing-masing kelompok umur 25-36

Tabel 2. Karakteristik dasar pasien rawat inap yang mengalami MRS

\begin{tabular}{lcc}
\hline Variabel & $\mathrm{n}$ & $\begin{array}{c}\text { MRS } \\
\mathrm{n}(\%)\end{array}$ \\
\hline $\begin{array}{l}\text { Jenis kelamin } \\
\text { Laki-laki }\end{array}$ & 720 & $81(0,11)$ \\
$\quad$ Perempuan & 566 & $69(0,12)$ \\
Umur (bulan) & & \\
$\quad 0-12$ & 343 & $51(0,14)$ \\
$13-24$ & 184 & $19(0,10)$ \\
$25-26$ & 98 & $16(0,16)$ \\
37-48 & 93 & $14(0,15)$ \\
$\quad 49-60$ & 55 & $2(0,03)$ \\
$\quad>60$ & 513 & $48(0,10)$ \\
Status gizi (saat MRS) & & \\
$\quad$ Baik & 606 & $49(0,8)$ \\
Kurang & 566 & $70(0,12)$ \\
$\quad$ Buruk & 114 & $31(0,27)$ \\
Diagnosis & & \\
$\quad$ Tunggal & 521 & $29(0,05)$ \\
$\quad$ Multipel & 765 & $121(0,15)$ \\
Lama rawat (hari) & & \\
2-7 & 967 & $70(0,07)$ \\
$\quad>7$ & 319 & $80(0,25)$ \\
Sub divisi & & \\
$\quad$ Infeksi & 511 & $89(0,17)$ \\
$\quad$ Non infeksi & 775 & $61(0,07)$ \\
\hline
\end{tabular}

bulan $\mathrm{p}=0,024$, gizi buruk $\mathrm{p}=0,000$, dengan diagnosis multipel $\mathrm{p}=0,000$, penyakit infeksi dengan nilai $\mathrm{p}=0,000$ dan lama rawat lebih dari 7 hari, $\mathrm{p}=0,000$ (Tabel 2).

\section{Pembahasan}

Untuk mendukung tercapainya gizi baik adalah sangat penting, menyusun dan mengimplementasikan protokol dan alur tata laksana yang baik sehingga dapat membantu dalam mewujudkan intervensi sedini mungkin yang seharusnya direncanakan oleh ahli gizi. ${ }^{6}$ Malnutrisi pada anak memiliki relevansi dan kepentingan dengan kesehatan masyarakat. Hal tersebut berhubungan langsung dengan kemiskinan, dan akibat terbesar dari masalah paling utama, yaitu kelaparan yang korban terbesarnya adalah anak-anak. ${ }^{7}$ Data menunjukkan bahwa malnutrisi pada anak masih sering dijumpai baik di negara maju maupun negara berkembang. Prevalensinya bervariasi antara 6,1\% sampai $11 \%$ di negara maju dan 6,9\% sampai $53 \%$ di negara berkembang. ${ }^{3}$ Kami menemukan 8,9\% prevalensi malnutrisi di RS Wahidin Sudirohusodo. Penelitian sebelumnya oleh Sidhiarta ${ }^{3}$ di RS Sanglah, Denpasar, Bali didapatkan prevalensi malnutrisi sebesar $20,8 \%$. Hal tersebut menjadi bahan pertimbangan bahwa masalah malnutrisi di masyarakat masih belum tertangani dengan baik sehingga prevalensinya cenderung meningkat.

Pada anak-anak dengan malnutrisi ini, cenderung menunjukkan peningkatan morbiditas, dan prevalensi pada saat masuk rumah sakit. Ketika mereka masuk umumnya tidak diperhatikan dengan baik dalam hal antropometriknya, dan pada akhirnya tidak ditunjang nutrisinya selama perawatan. Pemerintah telah mencanangkan tata laksana nutrisi rumah sakit dengan tujuan menurunkan insiden malnutrisi rumah sakit. Hal tersebut berdampak positif terhadap prognosis penyakit menjadi lebih baik melalui lima langkah tata laksana gizi, yaitu penentuan status nutrisi, penghitungan kebutuhan nutrisi, penentuan jenis nutrisi, penentuan cara pemberian nutrisi, dan evaluasi. $^{3}$

Kriteria malnutrisi rumah sakit dalam literatur belum jelas karena masing-masing peneliti menggunakan kriteria, sehingga sulit untuk membandingkan hasil penelitian satu dengan yang lainnya. Kami menggunakan kriteria Walker dan Hendricks yaitu 
penurunan berat badan $>2 \%$ dalam 1 minggu, $>5 \%$ dalam 1 bulan, $>7 \%$ dalam 3 bulan dan $>10 \%$ dalam 6 bulan. Kami mendapatkan anak dengan penurunan berat badan terbanyak adalah kurang dari $2 \%$. Hal tersebut berhubungan dengan tata laksana nutrisi di RS Wahidin Sudirohusodo yang sudah cukup baik, tetapi kemungkinan masih terjadi asupan yang tidak adekuat dikarenakan penyakit yang mendasarinya.

Beberapa variabel yang diperkirakan berhubungan dengan insiden MRS, seperti jenis kelamin, umur, diagnosis, status gizi, subdivisi, lama rawat, dan jenis penyakit dianalisis. Malnutrisi rumah sakit lebih banyak terjadi pada anak laki-laki dibandingkan perempuan, tetapi nampaknya bukan merupakan faktor risiko.

Dari hasil uji bivariat membuktikan bahwa MRS sering terjadi pada anak yang berusia 25-36 bulan, dan sudah mengalami malnutrisi sejak masuk rumah sakit, didiagnosis dengan lebih dari satu diagnosis, tergolong penyakit infeksi, serta lama rawat $>7$ hari. Hasil penelitian kami juga konsisten dengan hasil penelitian sebelumnya. ${ }^{3}$ Anak yang dirawat lebih dari 1 minggu memiliki risiko MRS 1,2 kali dibandingkan yang dirawat kurang dari 1 minggu. Anak yang dirawat lebih lama umumnya memilki diagnosis yang kompleks (multipel), dan berpenyakit kronis sehingga memiliki risiko lebih tinggi mengalami MRS. Kami membuktikan bahwa anak yang dirawat lebih dari seminggu 75,2\% dengan diagnosis multipel $59,5 \%$, dan terbanyak pada penyakit lain 26,1\%. Sesuai teori bahwa penyakit kronis dan kompleks akan menekan nafsu makan, menghambat penyerapan makanan, meningkatkan kebutuhan, dan mengganggu metabolisme sehingga semakin lama perawatan semakin tinggi risiko MRS. ${ }^{3}$

\section{Kesimpulan}

Disimpulkan bahwa prevalensi MRS 8,9\% di RS
Wahidin Sudirohusodo lebih rendah dibandingkan pada penelitian di RS Sanglah, Denpasar, Bali. Lama rawat yang dilatarbelakangi penyakit kronis dan diagnosis multipel masih menjadi faktor risiko MRS 1,2 kali lebih besar dibandingkan anak yang dirawat kurang dari seminggu. Serta penyakit dari subdivisi infeksi dengan faktor risiko 1,1 kali lebih besar daripada penyakit subdivisi non infeksi.

\section{Daftar pustaka}

1. Sjarif D, Lestari E, Mexitalia M, Nasar S. Malnutrisi rumah sakit. Dalam: Buku ajar nutrisi pediatrik dan penyakit metabolik. Jakarta: Ikatan Dokter Anak Indonesia; 2011.h.165-75.

2. Koen FM, Jessie MH. Prevalence of malnutrition in pediatric hospital patients. Rotterdam: Lippincott Williams \& Wilkins; 2008.h.590-95.

3. Sidiartha I.G. Malnutrisi rumah sakit pada anak di rumah sakit umum pusat Sanglah, Denpasar. Dalam: Kumpulan Naskah Lengkap PIT IV IKA Medan 2010. Medan: Ikatan Dokter Anak Indonesia; 2010.h.56-65.

4. Stephanie H.A, Robert J.S. Nutritional assesment of the hospitalized patient. In: Nutrition in Pediatrics. p.4915 .

5. Marino LV, Goddard E, Workman L. Determining the prevalence of malnutrition in hospitalized paediatric patients. In: SAMJ. Cape Town.p.993-5.

6. Rocha G.A, Rocha E.G, Martins C.V. The effects of hospitalization on the nutritional status of children. Dalam: Jornal de Pediatria. Brasil: Sociedade Brasileira de Pediatria. p.70-3.

7. Walker WA, Watkins JB, Duggan C. Nutrition in pediatrics. Basic science and clinical applications. London: BC Decker, 2003.

8. Hendricks KM, Duggan C, Gallagher L, Carlin AC, Richardson DS, Collier SB, dkk. Malnutrition in hospitalized pediatric patients. Current prevalence. Arch Pediatr Adolesc Med. 1995;149:1118-22. 